\title{
On-line Digestion in a Focused Microwave-Assisted Oven for Elements Determination in Orange Juice by Inductively Coupled Plasma Optical Emission Spectrometry
}

\author{
Sabrina P. Fili, Elisabeth Oliveira and Pedro V. Oliveira* \\ Instituto de Química, Universidade de São Paulo, 26077, 05513-970 São Paulo - SP, Brasil
}

\begin{abstract}
Um sistema de fluxo acoplado a um forno de microondas focalizadas foi utilizado para digestão em linha de amostras de suco de laranja para a determinação de $\mathrm{Ca}, \mathrm{Cu}, \mathrm{Fe}, \mathrm{K}, \mathrm{Mg}, \mathrm{Mn}, \mathrm{Na}, \mathrm{P}$ e Zn por espectrometria de emissão ótica com plasma indutivamente acoplado. Uma bobina de reação de PTFE (4,0 m de comprimento e 1,6 mm de diâmetro interno) foi posicionada no interior da cavidade de vidro do forno de microondas focalizadas. Alíquotas de $500 \mu \mathrm{L}$ de amostra e de $1000 \mu \mathrm{L}$ de reagente $\left(80 \% \mathrm{v} / \mathrm{v} \mathrm{HNO}_{3}\right)$ foram misturadas em uma confluência e conduzidas para a bobina de reação utilizando ar como carregador. O desvio padrão relativo para cinco determinações da mesma amostra usando o método proposto foi inferior a 5,0\%. Boas recuperações variando de 91 a $111 \%$ foram obtidas para adições de quantidades conhecidas dos elementos de interesse. Os resultados obtidos, utilizando o sistema de digestão proposto, foram concordantes a um nível de confiança de $95 \%$ com aqueles obtidos por digestão total. Com este método de digestão foi possível processar 12 amostras $\mathrm{h}^{-1}$, minimizando contaminações, consumo de amostra e reagentes e gerando pequena quantidade de resíduos.
\end{abstract}

A flow injection system coupled to focused microwave-assisted oven was used for on-line orange juice sample digestion for determination of $\mathrm{Ca}, \mathrm{Cu}, \mathrm{Fe}, \mathrm{K}, \mathrm{Mg}, \mathrm{Mn}, \mathrm{Na}, \mathrm{P}$, and $\mathrm{Zn}$ by inductively coupled plasma optical emission spectrometry. The reactor coil was a PTFE tube $(4.0 \mathrm{~m}$ long and $1.6 \mathrm{~mm}$ i.d.) positioned into the commercial glass tube of the focused microwave oven. Aliquots of $500 \mu \mathrm{L}$ of sample and $1000 \mu \mathrm{L}$ of reagent $\left(80 \% \mathrm{v} / \mathrm{v} \mathrm{HNO}_{3}\right)$ were mixed in a confluence and carried out to the reactor coil by air carrier. The relative standard deviation for five replicates of sample was lower than $5.0 \%$. Good recoveries varying from 91 to $111 \%$ were obtained for added concentrations of the interest elements. The results obtained using the proposed digestion system are in agreement with those obtained for total digestion at the $95 \%$ confidence level. With this on-line digestion system was possible to carry out 12 samples $\mathrm{h}^{-1}$, minimizing contamination, saving consumption of samples and reagent and low residue generation.

Keywords: on-line digestion, orange juice, focused microwave oven, atomic emission

\section{Introduction}

Major and trace elements levels in orange juice have been a subject of considerable interest due to the relationship between some elements and plant, animal and human nutrition. Additionally, some elements and organic constituents, mainly amino acids, can be used to monitor quality, authenticity and country of origin. ${ }^{1,2}$ Chemical characterization of the orange juice may be used to establish guidelines required for quality control monitoring. Adulteration can range from a simple addition of sugar solution to more sophisticated methods, as addition of pulp wash or peel extract to concentrate. Trace

* e-mail: pvolivei@iq.usp.br metal data are potentially more useful than the major elements for identifying the history of juice and detecting adulteration. ${ }^{1}$

Several spectrometry techniques have been used for macro and trace elements determination in orange juice: atomic absorption spectrometry with flame (FAAS), ${ }^{3-7}$ hydride (HGAAS) ${ }^{8,9}$ or electrothermal atomization (ETAAS), ${ }^{10,11}$ inductively coupled argon plasma optical emission spectrometry (ICP-OES), ${ }^{1,5,12-17}$ direct current argon plasma optical emission spectroscopy (DCP-OES), ${ }^{5}$ and inductively coupled plasma mass spectrometry (ICPMS). ${ }^{1,17}$

FAAS methods are restricted to major elements determination in orange juice due to the poor sensitivity. For trace elements, the most recommended techniques are 
ETAAS, ICP-OES and ICP-MS. Whereas simultaneous ICPOES or ICP-MS provide rapid multielement analysis which are highly desirable for adulteration investigations, a comparative study of the spectroscopic techniques for elements determination in orange, observing differences between methods with respect to convenience, analytical frequency, precision, detection limits and calibration procedures showed general agreement between final results for all methods. ${ }^{5}$ Frequently, the above techniques require introduction of liquid solution for elemental analysis. For this reason, a great number of samples are dissolved or digested in chemical laboratories, making this one of the most common operations within the total analytical procedure. $^{18}$

The usual methods applicable for orange juice sample preparation involve the organic matter destruction. Dry ashing in a muffle furnace, ${ }^{3,5,7,8,12,13}$ wet digestion procedure using a hot plate, ${ }^{4,10,14}$ or microwave-assisted oven ${ }^{9,12,13,15-17}$ have been used as orange juice sample preparation for elemental analysis. For some elements determination, such as $\mathrm{Al}$, a simple filtration has been proposed. ${ }^{11}$

In the last two decades sample preparation has been putting in evidence in many analytical methods published in the literature. ${ }^{19}$ Among these, alternative procedures by using flow systems coupled to microwave ovens are one of the most proposed for sample preparation. ${ }^{20-30}$ These systems save time, sample requirement and reagent consumption, accelerate the reaction through rapid heating, making it possible to generate reaction products quickly and in lager quantities ${ }^{20}$ Besides of these favorable characteristics, fume production during wet digestion, contamination and losses of volatile elements can be overcome or minimized when flow digestion systems coupled to the microwave oven are used. In a general way, the system in flow is incorporated to a microwave oven, and the digested sample is collected in flasks opened for subsequent analysis by some appropriate analytical technique or driven directly to the detector coupled in line with the microwave oven. Microwave ovens with big cavity, e.g., domestic or commercial are well suitable to couple on-line flow systems for sample digestion. A significant number of papers have described procedures based in this kind of configuration. ${ }^{20-23}$

In spite of the apparent facilities to couple an on-line flow systems, focused microwave-assisted ovens have not awoke to the interest for this arrangement. For this reason, an on-line flow system coupled to focused microwaveassisted oven is proposed for orange juice sample preparation for the determination of $\mathrm{Ca}, \mathrm{Cu}, \mathrm{Fe}, \mathrm{K}, \mathrm{Mg}$, $\mathrm{Mn}, \mathrm{Na}, \mathrm{P}$, and $\mathrm{Zn}$ by inductively coupled plasma optical emission spectrometry.

\section{Experimental}

\section{Apparatus}

A sequential inductively coupled plasma optical spectrometer Spectro Flame (Spectro Analytical Instruments GMBH, Kleve, Germany) equipped with quartz spray chamber torch and concentric nebulizer (Meinhard, TR-20-C1) was used. The instrumental and operational parameters used in this work are described in Table 1. All measurement was based on peak height emission intensity by OS/2 WARP 4 Operating System, with at least three replicates.

Table 1. Instrumental parameters for ICP-OES

\begin{tabular}{|c|c|}
\hline \multicolumn{2}{|l|}{ Parameter } \\
\hline RF generator & $27 \mathrm{MHz}$ \\
\hline Operating Power & $1200 \mathrm{~W}$ \\
\hline Cooling gas flow-rate & $12 \mathrm{~L} \mathrm{~min}^{-1}$ \\
\hline Auxiliary gas flow-rate & $1.2 \mathrm{~L} \mathrm{~min}^{-1}$ \\
\hline Nebulizer pressure & 3.0 bar $(300 \mathrm{kPa})$ \\
\hline Sample uptake & $1.8 \mathrm{~L} \mathrm{~min}^{-1}$ \\
\hline Observation height & $12 \mathrm{~mm}$ \\
\hline Spectral Wavelengths (nm) & $\begin{array}{l}\text { Optic } 1: \mathrm{Ca}=317.3 ; \mathrm{Cu}=324.7 ; \\
\mathrm{Fe}=259.9 ; \mathrm{Mg}=279.1 ; \\
\mathrm{Mn}=293.9 ; \mathrm{P}=178.3 ; \mathrm{Zn}=334.5 \\
\text { Optic } 2: \mathrm{Na}=559.0 ; \mathrm{K}=766.5\end{array}$ \\
\hline
\end{tabular}

Argon 99.96\% (v/v) (Air Liquid Brasil S/A, São Paulo, Brasil) was used as auxiliary, plasma and sample introduction gas.

The on-line flow system consisted of an Ismatec Model IPC-8 peristaltic pump (Ismatec, Switzerland) furnished with Tygon ${ }^{\circledR}$ pumping and PTFE conducing tubes $(0.8$ and $1.6 \mathrm{~mm}$ i.d.), a three-piece injector commutator with built-in T-shaped connectors (Figure 1, A), a focused microwave-assisted oven (Spex, Merceville, NJ, USA) equipped with a magnetron of $2450 \mathrm{MHz}$ with nominal maximum power of $300 \mathrm{~W}$, and reactor coil adapted in a cooler system (Figure 1, B). The PTFE reactor coil $(4.0 \mathrm{~m}$ long and $1.6 \mathrm{~mm}$ i.d.) (Figure 1,d) was introduced into the microwave oven glass cavity (Figure $1, \mathrm{c}$ ). The reactor coil extremities pass inside of a laboratory-made cooler system mounted in PVC tube (15 mm i.d. with $12 \mathrm{~cm}$ long) (Figure $1, \mathrm{e})$. The PVC extremities were closed with rubber stoppers (Figure 1, f), in each one were made two orifices to allow the through passage of the PTFE tube. The PTFE tubes inside the cooler system were coiled (Figure 1, g) to enhance the contact of these tubes with the cool water flowing into the cooler system. During the sample preparation, cool water flows throughout inside the cooler system (in) and (out). 


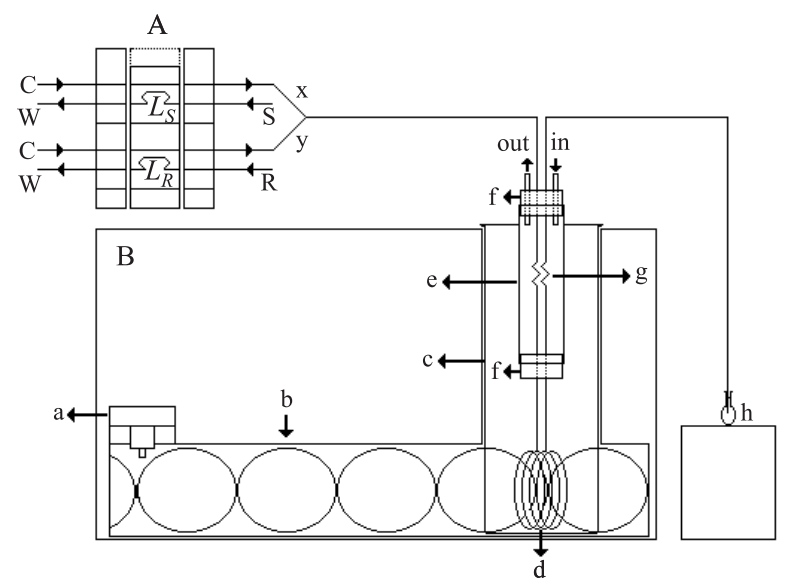

Figure 1. (A): Injector-commutator diagram; S: sample; R: reagent; C: carrier $\left(3.0 \mathrm{ml} \mathrm{min}^{-1}\right)$; W: waste; $\mathrm{L}_{\mathrm{s}}$ : sample loop; $\mathrm{L}_{\mathrm{R}}$ : reagent loop. (B): On-line focused microwave-assisted sample digestion diagram; a: magnetron; b: waveguide; c: glass cavity; d: PTFE reactor coil; e: PVC cooler system; f: rubber stopper; g: PTFE coils $(5 \mathrm{~cm})$; and $\mathrm{h}$ : volumetric flask $(10 \mathrm{~mL})$.

\section{Reagents, reference solutions and samples}

All solutions were prepared using high purity deionized water (resistivity $18.2 \mathrm{M} \Omega \mathrm{cm}$ ) obtained from a Milli-Q ${ }^{\circledast}$ water purification system (Millipore, Bedford, USA).

High purity reagents or analytical reagent-grade (Merck, Rio de Janeiro, Brasil) were used in all experiments. Hydrogen peroxide and nitric acid were used as reagent for sample preparation. It was purified by distillation in quartz sub-boiling still (Marconi Equipamentos de Laboratório, Piracicaba, Brasil).

Stock reference solutions of $1000 \mathrm{mg} \mathrm{L}^{-1}$ of $\mathrm{Ca}, \mathrm{Cu}, \mathrm{Fe}$, $\mathrm{K}, \mathrm{Mg}, \mathrm{Mn}, \mathrm{Na}, \mathrm{P}$, and $\mathrm{Zn}$ were prepared by dissolving Tritisol standard solution (Merck, Darmstadt, Germany), according the instructions of the manufacturer.

The multielement analytical reference solutions containing up to $2 \mathrm{mg} \mathrm{L}^{-1}$ of $\mathrm{Cu}$, Mn and $\mathrm{Zn}, 20 \mathrm{mg} \mathrm{L}^{-1}$ of $\mathrm{Na}, 40 \mathrm{mg} \mathrm{L}^{-1}$ of $\mathrm{Fe}, 200 \mathrm{mg} \mathrm{L}^{-1}$ of $\mathrm{Ca}, \mathrm{Mg}$ and $\mathrm{P}$, and $400 \mathrm{mg} \mathrm{L}^{-1}$ of $\mathrm{K}$ in $1.0 \% \mathrm{v} / \mathrm{v}$ of $\mathrm{HNO}_{3}$ were prepared by successive dilution of the stock reference solutions. These solutions were used for spectrometer calibration and for addition recovery texts.

Eight commercial orange juices purchased in supermarket were analyzed. All of them were integral juice without additives or water; seven were packing in Tetra Rex (Tetra Pak) case with screw cap and one was packing in plastic (Plaspac) case.

\section{Procedure}

All glassware and high-density polypropylene bottles
(Nalge Company, Rochester, USA) were cleaned with detergent solution, soaking in $10 \%$ (v/v) $\mathrm{HNO}_{3}$ during 24 $\mathrm{h}$, rinsed with Milli- ${ }^{\circledast}$ water, and stored into a closed polypropylene container. Analytical reference solutions were prepared in a Class-100 laminar flow hood (Veco, Campinas, SP, Brasil).

In the specified position (Figure 1, A), the loop sample $\left(L_{S}\right)$ and the loop reagent $\left(L_{R}\right)$, loaded with $500 \mu \mathrm{L}$ sample and $1000 \mu \mathrm{L}$ reagent solution, respectively, were inserted into the air carrier streams (Figure 1, C) at $3.0 \mathrm{~mL} \mathrm{~min}^{-1}$ and driven towards the confluence point. The distance between the injector-commutator and the confluence for the reagent carrier stream was the half of the sample carrier stream to allow the sampling zone formed by reagent + regent/ sample + reagent. The sampling zone was then directed towards to the PTFE reactor coil located inside the glass flask of the microwave oven (Figure 1, d). When the sampling zone attained the center of the digestion coil, in this system about $20 \mathrm{~s}$, the peristaltic pump was stopped and the microwave program (Table 2) was started. After this heating program, the peristaltic pump was re-started and high pure Milli- $\mathrm{Q}^{\circledast}$ water was introduced via the air carrier tubes in order to clear the residual decomposed sample inside the reactor coil. About $1 \mathrm{~mL}$ of water was introduced in both, sample and reagent channel. When water passes through the reactor coil, a new sample and reagent loops are injected. The digested sample zone and the water were collected directly into the volumetric flask $(10 \mathrm{~mL})$ (Figure 1, h).

Table 2. Heating program for the focused microwave-assisted

\begin{tabular}{ll}
\hline Total Digestion Method ${ }^{\text {a }}$ \\
\hline Water Evaporation (Step 1) & $45 \mathrm{~W}-15 \mathrm{~min}$ \\
Volume $\mathrm{HNO}_{3}$ & $5.0 \mathrm{~mL}$ \\
Sample Digestion (Step 2) & $30 \mathrm{~W}-5 \mathrm{~min}$ \\
& $45 \mathrm{~W}-10 \mathrm{~min}$ \\
& $60 \mathrm{~W}-5 \mathrm{~min}$ \\
Volume $\mathrm{H}_{2} \mathrm{O}_{2}$ & $2.0 \mathrm{~mL}$ \\
Sample Digestion (Step 3) & $60 \mathrm{~W}-10 \mathrm{~min}$
\end{tabular}

On-line Flow Digestion Method ${ }^{\text {b }}$

\begin{tabular}{lr}
\hline Step 1 & $10 \mathrm{~W}-1 \mathrm{~min}$ \\
Step 2 & $0 \mathrm{~W}-1 \mathrm{~min}$ \\
Step 3 & $10 \mathrm{~W}-1 \mathrm{~min}$
\end{tabular}

a Sample volume $=5.0 \mathrm{~mL}$, dilution to $25 \mathrm{~mL}$; ${ }^{\text {b }}$ Sample Volume 0.5 $\mathrm{mL}$, dilution to $10 \mathrm{~mL}$.

Orange juice samples were also digested by conventional system of the focused microwave-assisted oven. For this purpose, $5.0 \mathrm{~g}$ of the orange juice samples were accurately weighed and added with $5 \mathrm{~mL}$ of concentrated $\mathrm{HNO}_{3}$ in the digestion vessel and a heating program was executed. After than, $1 \mathrm{~mL}$ of $\mathrm{H}_{2} \mathrm{O}_{2}$ was added and other 
heating program was performed (Table 2). After that the solution was diluted to $25.0 \mathrm{~mL}$ with Milli-Q ${ }^{\circledR}$ water and analyzed by ICP-OES

Due to the incomplete digestion in the on-line sample decomposition system, small particles persisted in the solution. To prevent Meinhard nebulizer clogging, before the introduction to the ICP-OES, the solutions were filtered in a circular net of Nylon adapted to a PTFE filtration unit, as described in the literature. ${ }^{31}$ After each sampling the filter was rinsed with $0.1 \% \mathrm{v} / \mathrm{v}$ of $\mathrm{HNO}_{3}$ in counter-flow. The ICP-OES sample uptake was matched with the

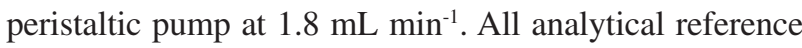
solutions and the sample solutions processed by conventional digestion were also introduced by this flow system to avoid the inadequate calibration of the ICPOES and results misjudgment.

The procedures using total digestion and a simple filtration were applied for four orange juices to verify the necessity of sample pretreatment.

Recovery tests were performed by adding $0.5 \mathrm{mg} \mathrm{L}^{-1}$ of $\mathrm{Cu}, \mathrm{Mn}$ and $\mathrm{Zn}, 5 \mathrm{mg} \mathrm{L}^{-1}$ of $\mathrm{Na}, 10 \mathrm{mg} \mathrm{L}^{-1}$ of Fe, $50 \mathrm{mg} \mathrm{L}^{-1}$ of $\mathrm{Ca}, \mathrm{Mg}$ and $\mathrm{P}$, and $100 \mathrm{mg} \mathrm{L}^{-1}$ of $\mathrm{K}$ to orange juice before and after on-line and conventional digestion procedure.

\section{Results and Discussion}

\section{General considerations}

The interest for analytical procedures that avoid the complete digestion of solid or liquid samples has been considerably increased in the last years. It is important to stand out that, for some spectroscopy techniques previously mentioned and considering the sample characteristic, in some cases, laborious pretreatment is unnecessary. In this way, microwave-assisted pretreatment accomplished only by an extraction of the interest element for the aqueous phase, dispensing the lengthy process of the total digestion, saving time and energy requirements are interesting of the analytical point view.

At the first glance, the on-line focused microwaveassisted sample decomposition proposed in this work does not allow a high energetic condition (pressure and temperature) for total samples digestion. The sample zone expansion going out of the microwave region is the main obstacle to get a more aggressive decomposition conditions. However, a moderate heating condition associated to an adequate reaction medium is sufficient to allow the interest element extraction, as observed for orange juice in the on-line decomposition developed in this work.

The direct introduction of the orange juice in an atomic absorption or emission spectrometer through pneumatic nebulization is unfeasible due to the dissolved solids that could provoke capillary tube blockage. On the other hands, the high solids content and the different particle size presented in orange juice to render impossible the direct sample introduction, even so by using special sample introduction system for ICP-OES. In this case, centrifugation or filtration to remove large particles is the recommended procedure before the analysis. Notwithstanding, this procedure consumes a long time (about $1 \mathrm{~h}$ to achieve some milliliters with normal filtration), can introduce contamination, and can prejudice the accuracy of the method, some elements associated to the cellular material should be separated in the solid fraction, producing erroneous results. The determination of $\mathrm{Ca}, \mathrm{Cu}, \mathrm{K}, \mathrm{Mg}$ and $\mathrm{P}$ in the total digested and in the filtrated orange juices showed that the necessity of pretreatment is imperative. For four orange juices determined, $\mathrm{Mg}, \mathrm{P}, \mathrm{K}, \mathrm{Ca}$, and $\mathrm{Cu}$ concentrations found in the filtrated were always lower than those obtained for total digestion (Table 3). Phosphorus

Table 3. Comparison of the elements concentration $\left(\mathrm{mg} \mathrm{L}^{-1}\right)$ in orange juice by using total digestion and filtration

\begin{tabular}{|c|c|c|c|c|c|}
\hline & $\mathrm{Mg}$ & $\mathrm{P}$ & $\mathrm{K}$ & $\mathrm{Ca}$ & $\mathrm{Cu}$ \\
\hline \multicolumn{6}{|l|}{ Sample A } \\
\hline Total Digestion & $123 \pm 2$ & $237 \pm 3$ & $1651 \pm 22$ & $117 \pm 2$ & $0.36 \pm 0.01$ \\
\hline Filtration & $110 \pm 1$ & $194 \pm 2$ & $1462 \pm 3$ & $110 \pm 4$ & $0.27 \pm 0.01$ \\
\hline \multicolumn{6}{|l|}{ Sample B } \\
\hline Total Digestion & $114 \pm 4$ & $197 \pm 6$ & $2154 \pm 30$ & $98 \pm 2$ & $0.25 \pm 0.02$ \\
\hline Filtration & $107 \pm 1$ & $149 \pm 1$ & $1991 \pm 4$ & $68 \pm 13$ & $0.15 \pm 0.01$ \\
\hline \multicolumn{6}{|l|}{ Sample C } \\
\hline Total Digestion & $130 \pm 1$ & $202 \pm 2$ & $2021 \pm 7$ & $95 \pm 1$ & $0.28 \pm 0.01$ \\
\hline Filtration & $123 \pm 1$ & $163 \pm 1$ & $1951 \pm 9$ & $80 \pm 1$ & $0.23 \pm 0.01$ \\
\hline \multicolumn{6}{|l|}{ Sample D } \\
\hline Total Digestion & $137 \pm 1$ & $202 \pm 1$ & $1863 \pm 2$ & $67 \pm 1$ & $0.26 \pm 0.01$ \\
\hline Filtration & $131 \pm 1$ & $144 \pm 1$ & $1857 \pm 12$ & $79 \pm 1$ & $0.21 \pm 0.01$ \\
\hline
\end{tabular}


and $\mathrm{Cu}$ showed the worst recovery for filtration in comparison with total digestion, about 80 and $70 \%$, respectively.

\section{On-line focused microwave-assisted system optimization}

Despite the apparent facility to adapt an on-line flow system to the focused microwave-assisted oven, it is not too easy. One of the most acute difficulties is to maintain the sample and reagent, inside the reactor coil, in the microwave-assisted region during the heating program. It was observed that the sample zone expansion due to the temperature and gases-formation inside de reactor coil is very intense.

No modification was made to the focused microwaveassisted oven to adapt the on-line flow system. For the proposed on-line flow digestion system different reactors lengths $(1.0,2.0$ and $4.0 \mathrm{~m})$ and internal diameters $(0.8$ and $1.6 \mathrm{~mm}$ ) were tested. These reactors were made of PTFE and the tubes were coiled and put into the original glass cavity of the microwave oven. PTFE tube was used throughout in this work because other material, such as polypropylene, was deformed during the heating program. In all experiments by using reactor coil of $0.8 \mathrm{~mm}$ i.d., the pressure generated inside the system was so intense that the sample zone was extended along of the all PTFE tube extension, even for the reactor length of $4.0 \mathrm{~m}$. For this reason, reactors coil of $1.6 \mathrm{~mm}$ i.d. were tested. The expansion during the heating program was minimized with this PTFE dimension tubes, being the minor effect observed for reactor length of $4.0 \mathrm{~m}$. However, the expansion of solution persisted.

The introduction of a cooler system mounted in PVC tube in the reactor coil extremities (Figure 1, e) drastically minimized the expansion of the sample zone inside the PTFE tube. During the on-line digestion procedure, cool water flow through this system all time. Besides the reduction expansion, the cooler system refrigerated the digested solution before the reception in the volumetric flask. The PTFE reactor coil with $4.0 \mathrm{~m}$ long and $1.6 \mathrm{~mm}$ internal diameter were chose for the next experiments.

The sample zone size inside the reactor coil is dependent to the sample and reagent volumes. For optimizatiom, 250, 500 and $1000 \mu \mathrm{L}$ sample loops and 500,1000 and $2000 \mu \mathrm{L}$ reagent loops were tested. To allow the complete interaction of the sample with the reagent, the reagent loop was bigger than sample loop and, in the flow system, the distance " $y$ " was the half of the distance " $x$ " (Figure 1, A) to allow the complete insertion of the orange juice in the reagent, forming a sample zone with reagent + sample/regent + reagent. The dilution factor and the sample zone extension were considered to choose the loops size.

The flow rate was not critical in this proposed on-line flow digestion system. The adoption of $3.0 \mathrm{~mL} \mathrm{~min}^{-1}$ allowed the sample zone solution attained the reactor coil in $20 \mathrm{~s}$. Higher peristaltic flow rate is not recommended because the digested solution passing through the PVC cooling system is not refrigerated before the volumetric flask.

\section{On-line orange juice sample decomposition}

In order to establish the best conditions for orange juice sample preparation by using the proposed on-line flow digestion system, the optimum sample and reagent loops volume, reagent concentration and composition, the heating program, and the dilution factor used for elements determination by using ICP-OES were studied.

By using the proposed on-line decomposition system (Figure 1) with PTFE reactor coil (4.0 m long and $1.6 \mathrm{~mm}$ i.d.) and considering the expansion and dilution factor, the best results were obtained by using $500 \mu \mathrm{L}$ of orange juice loop sample with $1000 \mu \mathrm{L}$ of reagent loop. As discussed in the previous section, for the low sample loop tested $(250 \mu \mathrm{L})$, and considering the dilution to $10 \mathrm{~mL}$, the final concentrations of the micro constituents $(\mathrm{Cu}, \mathrm{Fe}$, $\mathrm{Mn}$, and $\mathrm{Zn}$ ) were lower than the detection limits. On the other hand, for $1000 \mu \mathrm{L}$, the sample size volume formed with reagent occupied a big part of the reactor coil, intensifying the expansion inside the PTFE tube.

To verity the influence of the nitric acid concentration on the quantitative elements extraction of the orange juice, 10,50 and $80 \% \mathrm{v} / \mathrm{v}$ of this reagent were tested. A clear solution was obtained when $80 \% \mathrm{v} / \mathrm{v} \mathrm{HNO}_{3}$ was used as reagent. When 10 or $50 \%$ nitric acid concentration were used it was possible to observe a lot of orange juice particle in the digested solution. The recovery for all elements by using 10 or $50 \%$ nitric acid concentration were about $81 \pm$ $6 \%$ and $87 \pm 5 \%$ in comparison with the total digestion procedure (Table 2), respectively. The results obtained with these nitric acid concentrations were similar to those obtained for orange juices filtration. Concentrated nitric acid $(67 \% \mathrm{~m} / \mathrm{v})$ was avoided due to the observed corrosion in the injector-commutator metallic parts and the fume evolution in the lab ambient. Specifically for orange juice sample decomposition, the addition of hydrogen peroxide in the reagent did not cause benefices. On the contrary, the gases evolution was improved and, consequently, the sample zone expansion.

The heating program was also a critical parameter. The microwave oven used in this work has only time control, 
and the minimal time for applying a specific percentage of the total microwave power $(300 \mathrm{~W})$ is $1.0 \mathrm{~min}$. The minor power was always selected $(10 \%-30 \mathrm{~W})$ to avoid overheating of the solution inside the PTFE reactor coil.

The microwave-assisted heating time in the on-line orange juice decomposition was studied (Figure 2). It is important to comment that a step without microwave application was intercepted between others steps with application of $30 \mathrm{~W}$ during $1 \mathrm{~min}$. To get $5 \mathrm{~min}$ of microwave-assisted time the heating program (Table 2) had a total time of $10 \mathrm{~min}$. It can be seem (Figure 2) that sodium presented the same result with or without microwave heating, showing that this element can be determined by using a simple orange juice dilution. For $\mathrm{Ca}, \mathrm{K}$ and $\mathrm{Mg}$, after 2 min of microwave-assisted heating the same results were observed for normalized concentration up to $5 \mathrm{~min}$. For the others elements $(\mathrm{Cu}, \mathrm{Fe}, \mathrm{Mn}$ and $\mathrm{Zn}$ ), the same behavior were observed, from $2.0 \mathrm{~min}$ up to $5.0 \mathrm{~min}$ the normalized concentrations were practically the same. For phosphorus only $1.0 \mathrm{~min}$ of heating was necessary. Based in this results $2.0 \mathrm{~min}$ of microwave-assisted heating time were adopted. However, the continue heating during $2.0 \mathrm{~min}$ provoked over-heating

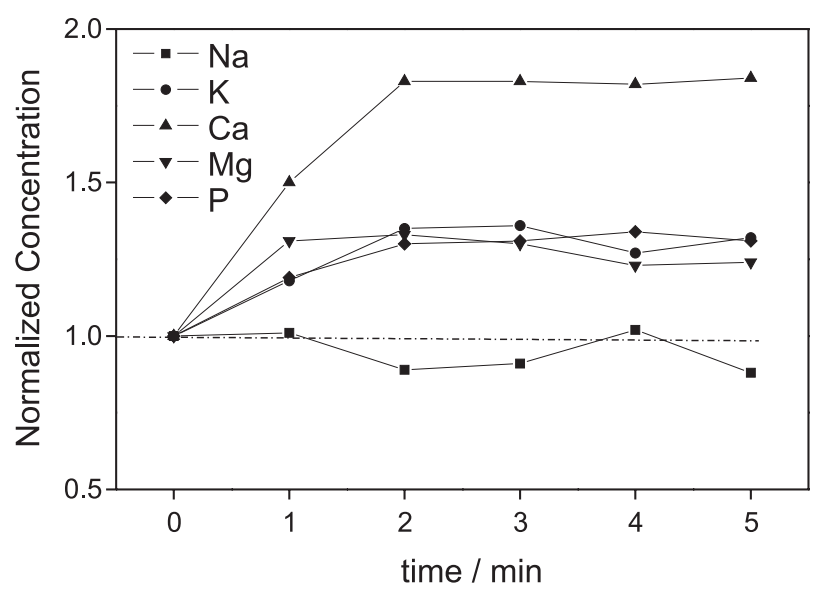

Figure 2. Effect of heating program time in the analytical results. of the solution and an intense expansion of the sample zone. To overcome this effect, a heating program intercalating $1.0 \mathrm{~min}$ without microwave application (Table 2) was adopted. This strategy allowed to work up to 5 min of microwave-assisted heating time without overheat and sample zone expansion.

\section{Elements determination in orange juices}

Under optimal on-line flow injection sample digestion and ICP-OES conditions, orange juices samples were analyzed by using the proposed on-line procedure (Table 4). Applying $t$-test, the results by using total and on-line sample pretreatment were found to be similar at the $95 \%$ confidence level. Potassium and sodium concentration of sample II are higher than those found for others orange juices. This specific orange juice sample was not a natural juice, in the manufacturer was added soy flour that was informed in the case specifications.

Addition of the interest elements to an orange juice before the on-line flow digestion procedure presented good recoveries (91 to 111\%) for all interest elements.

The results obtained for orange juices are in accordance with others presented in the literature, using different sample preparation procedures (Table 5).

Table 5. Average elemental composition for orange juices from different countries

\begin{tabular}{cccc}
\hline \multirow{2}{*}{ Element } & \multicolumn{3}{c}{ Concentration $\left(\mathrm{mg} \mathrm{L}^{-1}\right)$} \\
& This Work $^{\mathrm{a}}$ & Brazil $^{\mathrm{b}}$ & Other $^{\mathrm{b}}$ \\
\hline $\mathrm{Al}$ & $0.15-0.57$ & $0.06-5.67$ & $0.1-0.7$ \\
$\mathrm{Ca}$ & $36-135$ & $77-120$ & $87-150$ \\
$\mathrm{Cu}$ & $0.11-0.21$ & $0.15-0.40$ & $0.1-0.4$ \\
$\mathrm{Fe}$ & $0.92-3.6$ & $0.80-7.49$ & $1.1-8.5$ \\
$\mathrm{~K}$ & $1981-2566$ & $2030-3097$ & $1245-2465$ \\
$\mathrm{Mg}$ & $102-208$ & $107-170$ & $82-155$ \\
$\mathrm{Mn}$ & $0.38-0.56$ & $0.22-0.79$ & $0.2-0.9$ \\
$\mathrm{Na}$ & $0.46-1.30$ & $0.89-25.5$ & $2.5-43.3$ \\
$\mathrm{P}$ & $176-221$ & $155-308$ & $104-309$ \\
$\mathrm{Zn}$ & $0.26-0.35$ & $0.26-0.53$ & $0.2-0.5$ \\
\hline
\end{tabular}

${ }^{\mathrm{a}} \mathrm{n}=8$; by using the on-line flow digestion system.

Table 4. Elements concentrations in orange juices $\left(\mathrm{mg} \mathrm{L}^{-1}\right)$

\begin{tabular}{|c|c|c|c|c|c|c|c|c|}
\hline \multirow[b]{2}{*}{ Element } & \multicolumn{8}{|c|}{ On-line Sample Digestion Procedure } \\
\hline & I & II & III & IV & $\mathrm{V}$ & VI & VII & VIII \\
\hline $\mathrm{Ca}$ & $57 \pm 1$ & $135 \pm 3$ & $46 \pm 2$ & $36 \pm 1$ & $64 \pm 1$ & $63 \pm 2$ & $69 \pm 1$ & $49 \pm 3$ \\
\hline $\mathrm{Cu}$ & $0.11 \pm 0.03$ & $0.12 \pm 0.04$ & $0.18 \pm 0.02$ & $0.12 \pm 0.03$ & $0.21 \pm 0.05$ & $0.20 \pm 0.02$ & $0.21 \pm 0.04$ & $0.17 \pm 0.03$ \\
\hline $\mathrm{Fe}$ & $1.4 \pm 0.2$ & $3.6 \pm 0.6$ & $3.0 \pm 0.2$ & $16.4 \pm 0.5$ & $2.3 \pm 1$ & $0.9 \pm 0.5$ & $0.9 \pm 0.5$ & $0.7 \pm 0.4$ \\
\hline $\mathrm{K}$ & $2214 \pm 7$ & $589 \pm 10$ & $2399 \pm 39$ & $2264 \pm 9$ & $2566 \pm 19$ & $2288 \pm 14$ & $1981 \pm 11$ & $2211 \pm 7$ \\
\hline $\mathrm{Mg}$ & $208 \pm 7$ & $46 \pm 2$ & $118 \pm 9$ & $102 \pm 8$ & $110 \pm 4$ & $115 \pm 7$ & $104 \pm 5$ & $133 \pm 3$ \\
\hline $\mathrm{Mn}$ & $0.56 \pm 0.12$ & $0.49 \pm 0.07$ & $0.44 \pm 0.01$ & $0.38 \pm 0.16$ & $0.21 \pm 0.02$ & $0.44 \pm 0.01$ & $0.23 \pm 0.05$ & $0.36 \pm 0.05$ \\
\hline $\mathrm{Na}$ & $<\mathrm{LD}$ & $105 \pm 2$ & $0.46 \pm 0.02$ & $<\mathrm{LD}$ & $<\mathrm{LD}$ & $<\mathrm{LD}$ & $<\mathrm{LD}$ & $<\mathrm{LD}$ \\
\hline $\mathrm{P}$ & $180 \pm 3$ & $48 \pm 3$ & $185 \pm 2$ & $176 \pm 2$ & $216 \pm 2$ & $210 \pm 1$ & $198 \pm 2$ & $221 \pm 3$ \\
\hline $\mathrm{Zn}$ & $<\mathrm{LD}$ & $0.99 \pm 0.35$ & $0.93 \pm 0.23$ & $0.34 \pm 0.05$ & $<\mathrm{LD}$ & $0.35 \pm 0.07$ & $0.28 \pm 0.11$ & $0.26 \pm 0.04$ \\
\hline
\end{tabular}

I to VIII are orange juice samples; $\mathrm{LD}=$ Limit of Detection (Na) $0.026 \mathrm{mg} \mathrm{L}^{-1}$ and ( $\left.\mathrm{Zn}\right) 0.050 \mathrm{mg} \mathrm{L}^{-1}$. 


\section{Conclusions}

The proposed on-line focused microwave-assisted digestion system allowed 12 samples $^{-1}$ against 1 sample $\mathrm{h}^{-1}$ by using the conventional focused microwave-assisted oven for total sample digestion. It is important to emphasize that in this analytical frequency the pretreatment and cooling of the sample solution and ICP-OES determination time are considered. Additionally, in the proposed on-line decomposition system sample and reagent consume are minimized and low residue is generated.

This proposed system is the first attempt to couple an on-line system to a commercial focused microwave-assisted oven. Only small modifications in this on-line digestion system are necessary to adjust this system to other liquid samples or by using slurry.

Finally, this on-line pointed out the possibility of a more complete mechanization by using solenoid valves and a microcomputer, reducing the action of the analyst.

\section{Acknowledgments}

We thank Fundação de Amparo à Pesquisa do Estado de São Paulo for financial support (FAPESP - Proc. 2000/ 06796-1 and 2001/07048-1). S.P. Fili thanks Conselho Nacional de Desenvolvimento Científico e Tecnológico (CNPq) for scholarship.

\section{References}

1. Simpkins, W.A.; Louie, H.; Wu, M.; Harrison, M.; Goldberg, D.; Food Chem. 2000, 71, 423.

2. Robards, K.; Antolovich, M.; Analyst 1995, 120, 1.

3. McHard, J.A.; Winefordner, J.D.; Attaway, J.A.; J. Agric. Food Chem. 1976, 24, 41.

4. McHard, J.A.; Winefordner, J.D.; Ting, S.; J. Agric. Food Chem. 1976, 24, 950.

5. McHard, J.A.; Foulk, S.J.; Nikdel, S.; Ullman, A.H.; Pollard, B.D.; Winefordner, J.D.; Anal. Chem. 1979, 51, 1613.

6. McHard, J.A.; Foulk, S.J.; Winefordner, J.D.; J. Agric. Food Chem. 1979, 27, 1326.

7. Cohen, E.; Sharon, R.; Volman, L.; Hoenig R.; Saguy, I.; $J$. Food Sc. 1984, 49, 987.

8. Cervera, M.L.; Lopez, J.C.; Montoro, R.; Microchem. J. 1994, 49,20 .
9. Gallignani, M.; Valero, M.; Brunetto, M.R.; Burguera, J.L.; Burguera, M.; Peña, Y.P.; Talanta 2000, 52, 1015.

10. Wang, Y.; Lu, C.; Xiao, Z.; Kuan, S.S.; Rigsby, E.J.; J. Agric. Food Chem. 1991, 39, 724.

11. Arruda, M.A.Z.; Gallego, M.; Valcárcel, M.; Anal. Chem. 1993, 65,3331 .

12. Nikdel, S.; Temelli, C.M.; Microchem. J. 1987, 36, 240.

13. Rezaaiyan, R.; Nikdel, S.; J. Food Sci. 1990, 55, 1359.

14. Nikdel, S.; Mackeller, D.G.; Rezaaiyan, R.; J. Agric. Food Chem. 1991, 39, 1773.

15. Barnes, K.W.; At. Spectrosc. 1997, 18, 84.

16. Ulrich, N.; Anal. Chim. Acta 2000, 417, 201.

17. Schwartz, R.S.; Hecking, L.T.; J. Anal. At. Spectrom. 1991, 6, 637

18. Iyengar, G. V; Subramanian, K. S.; Woittiez, J. R. W.; Element Analysis of Biological Samples Principles and Practice, CRC Press: Boca Raton, New York, 1997.

19. Smith, F. E.; Arsenault, E. A.; Talanta 1996, 43, 1207.

20. Pereira-Filho, E.R.; Rohwedder, J.J.R.; Arruda, M.A.Z.; Analyst 1998, 123, 1023.

21. Pereira, A.V.; Aniceto, C.; Fatibello-Filho, O.; Analyst 1998, 123, 1011.

22. Burguera, M.; Burguera, J.L.; Anal. Chim. Acta 1998, 366, 63.

23. Noh, M.F.M.; Hamid, T.A.; Ismail, T.; At. Spectrosc. 1998, 19,95 .

24. LaFuente, J.M.G.; Marcahnte-Gayon, J.M.; Sanchez, M.L.F.; Sanz-Medel, A.; Talanta 1999, 50, 207.

25. Pereira-Filho, E.R.; Arruda, M.A.Z.; Analyst 1999, 124, 1873.

26. Xiang, Y.Q.; Chen, X.G.; Li, G.B.; Hu, Zhao, Z.F.; Hooper, M.; Lab. Rob. Automation 2000, 12, 91.

27. Neira, J.Y.; Reyes, N.; Nóbrega, J.A.; Lab. Rob. Automation 2000, 12, 246

28. Rouseff, R. L., Ting, S. V.; Citrus Fruits and Their Products: Analysis - Technology, Marcel Dekker: New York, 1986.

29. Oliveira, A. F.; Fatibello-Filho, O.; Talanta 1999, 50, 899.

30. Oliveira, A. F.; Fatibello-Filho, O.; Nóbrega, J. A.; Talanta 2001, 55, 677.

31. Fatibello-Filho, O.; Nóbrega, J. A.; Guaritá-Santos, A. J. M.; Talanta 1994, 41, 731.

Received: January 29, 2002 Published on the web: May 8, 2003

FAPESP helped in meeting the publication costs of this article. 